\title{
CORRECTION
}

\section{Correction: Eribulin rapidly inhibits TGF- $\beta$-induced Snail expression and can induce Slug expression in a Smad4-dependent manner}

Roma Kaul, April L. Risinger and Susan L. Mooberry (D)

British Journal of Cancer (2021) 124:855; https://doi.org/10.1038/s41416-020-01115-w

Correction to: British Journal of Cancer (2019) 121, 611-621; https://doi.org/10.1038/s41416-019-0556-9, published online 4 September 2019

Since the publication of this paper, the authors have realised that the identification of the Smad2/3 antibody used was incorrect in Supplementary Table 1. The corrected identification of the Smad2/ 3 antibody is Cell Signaling Technologies, 8685 (D7G7). Supplementary Table 1 has been corrected accordingly. The authors would like to apologise for this error which does not alter the conclusions of the paper.

\begin{abstract}
Open Access This article is licensed under a Creative Commons Attribution 4.0 International License, which permits use, sharing, adaptation, distribution and reproduction in any medium or format, as long as you give appropriate credit to the original author(s) and the source, provide a link to the Creative Commons license, and indicate if changes were made. The images or other third party material in this article are included in the article's Creative Commons license, unless indicated otherwise in a credit line to the material. If material is not included in the article's Creative Commons license and your intended use is not permitted by statutory regulation or exceeds the permitted use, you will need to obtain permission directly from the copyright holder. To view a copy of this license, visit http://creativecommons. org/licenses/by/4.0/.
\end{abstract}

(c) The Author(s) 2020 